\title{
Efektivitas Pembelajaran Dalam Jaringan (Daring) Selama Pandemi Covid-19 Di Kabupaten Jombang
}

\author{
${ }^{1}$ Fauziah Hanum, ${ }^{2}$ Heylen Amildha Yanuarita \\ Administrasi Publik, Universitas Kadiri \\ Email Korespondensi: hanum@unik-kediri.ac.id
}

\begin{abstract}
This research was conducted to determine the effectiveness of online learning for students in Jombang Regency, East Java during the pandemic period due to COVID-19. The method used in this research is descriptive qualitative method with the addition of a simple literature review review. This technique is used to get a detailed and comprehensive description and explanation of existing data. Where data retrieval was carried out with a more in-depth approach to the subject, assisted by various pre-existing literature reviews. The results indicate that the online learning process during the pandemic is still not optimal. This is due to the many obstacles experienced, such as a lack of infrastructure such as internet devices and networks, as well as a lack of digital media literacy in the community.
\end{abstract}

\section{Keywords: Distance learning, Covid-19 pandemic, Effectiveness of online learning}

Abstrak. Penelitian ini dilakukan untuk mengetahui bagaimana efektivitas pembelajaran dalam jaringan (daring) peserta didik di Kabupaten Jombang, Jawa Timur selama masa pandemi akibat COVID-19. Metode yang digunakan dalam penelitian ini adalah metode kualitatif deskriptif dengan tambahan tinjauan studi literatur sederhana. Teknik ini digunakan untuk mendapat gambaran dan penjelasan secara detail dan menyeluruh mengenai data-data yang ada. Dimana pengambilan data dilakukan dengan proses pendekatan terhadap subjek secara lebih mendalam, dibantu dengan berbagai tinjauan literatur yang sudah ada sebelumnya. Hasil penelitian mengindikasikan bahwa proses belajar daring selama masa pandemi masih belum optimal. Hal ini disebabkan banyaknya kendala yang dialami seperti kekurangan sarana prasarana layaknya gawai dan jaringan internet, serta kurangnya tingkat literasi media digital masyarakat.

Kata kunci: Pembelajaran jarak jauh, Pandemi Covid-19, Efektivitas belajar online

\section{PENDAHULUAN}

Pandemi Covid-19 yang melanda dunia, tidak terkecuali Indonesia, membawa berbagai dampak dan juga pengaruh bagi masyarakat. Setelah kisaran 8 bulan berlalu, virus corona masih juga menjangkiti beberapa masyarakat di Indonesia. Berdasarkan data yang didapatkan dari Worldometers (2020), kasus infeksi corona di Indonesia 502.110 orang, dengan pasien sembuh 422.386 orang dan pasien meninggal sebanyak 16.002 orang. Data ini terakhir diambil pada 23 November 2020. Seperti yang diketahui, COVID-19 merupakan penyakit menular, dimana virus yang merupakan cikal bakal penyakit ini bisa menyebar kemana saja, baik secara langsung atau tidak langsung, dari satu orang ke orang yang lain. Ketika seseorang terjangkiti oleh virus corona tersebut, maka sistem pernapasanlah yang akan diserang. Seperti misalnya hidung, tenggorokan, dan paru-paru. (Ririn, 2020)

Belum usainya kasus COVID-19 menandakan bahwa betapa rumitnya penanganan wabah atau pandemi. Apalagi sampai saat ini, belum ditemukannya vaksin atau obat untuk penyembuhan pasien Covid19. Meskipun secara perlahan, pasien yang sembuh pun cukup banyak dan menjadi kegembiraan tersendiri. Banyaknya pasien sembuh, tidak serta merta membuat pemerintah membebaskan masyarakat begitu saja. Faktanya, hingga saat ini kegiatan masyarakat masih dibatasi. Hal ini dilakukan dengan melakukan pembatasan interaksi 
masyarakat yang diterapkan dengan istilah physical distancing (Sohrabi, 2020)

Jika berbicara dari sudut pandang hubungan internasional, penyebaran virus corona telah berdampak luar biasa bagi setidaknya dua ruang lingkup, yaitu aktor (level of analysis) dan aspek (aspects or issues). Pertama, penyebaran virus ini telah berdampak luar biasa setiap tingkatan aktor, mulai dari individu, komunitas, masyarakat luas, perusahaan atau pihak swasta, negara bahkan global. Kedua, wabah penyakit dan penyebaran COVID-19 jelas telah berdampak pada berbagai aspek kehidupan, yang terutama adalah aspek kesehatan, selain juga aspek sosial, ekonomi, politik, bahkan pendidikan. Maka dapat dikatakan bahwa situasi ini telah melahirkan ancaman keamanan bagi manusia (human security) sekaligus bagi negara (state security) dan lebih luas lagi yaitu secara global (global security) (Deutsch, 2020).

Dalam pemberlakuannya, pemerintah membatasi setiap kegiatan masyarakat untuk meminimalisir penyebaran virus. Jika biasanya sekolah tatap muka, maka sekarang via online. Pun, orang-orang yang bekerja jika biasanya pergi ke kantor, sejak pandemi harus bekerja dari rumah. Keputusan pemerintah untuk meliburkan para peserta didik, memindahkan proses belajar mengajar di sekolah menjadi di rumah dengan menerapkan kebijakan Work From Home (WFH) yang menurut Yuliana (2020), faktanya masih membuat resah banyak pihak.

Kebijakan WFH ini tertuang dalam Surat Edaran Menteri Pendayagunaan Aparatur Negara dan Reformasi Birokrasi (PAN \& RB) Nomor 50/2020 tentang Perubahan Kedua atas Surat Edaran Menteri PAN \& RB Nomor 19/2020 tentang Penyesuaian Sistem Kerja Aparatur Sipil Negara dalam Upaya Pencegahan Penyebaran Covid-19 di Lingkungan Instansi Pemerintah (Mustakim, 2020) Sebagai ASN, guru dalam upaya melaksanakan proses pembelajaran perlu dilakukan secara online atau dalam jaringan (daring). Akibatnya, para peserta didik dan pihak-pihak lainnya yang terkait perlu menyesuaikan diri dengan metode belajar daring atau belajar online tersebut.
Proses belajar di masa pandemi yang dilakukan daring belum juga usai. Selang hampir 8 bulan lamanya, para siswa dan anakanak masih belajar di rumah. Begitu pun dengan para guru yang melakukan pengajaran di rumahnya masing-masing. Meskipun terkadang, ada juga yang harus melakuan pengajaran di sekolah langsung hingga terpaksa mendatangi rumah ke rumah siswa. Banyak kita lihat pemberitaan media yang tersebar dimana-mana. Siswa yang merasa kesulitan belajar, tugas-tugas yang menumpuk. Pun, orang tua atau wali murid yang juga dibuat kelimpungan membantu proses belajar anaknya. Belum lagi, para guru yang juga sama dibuat getir oleh pembelajaran daring.

Pada penelitian kali ini, penulis mencoba menakar dan menganalisis bagaimana proses belajar daring dilakukan. Khususnya di salah satu daerah Jawa Timur yakni Kabupaten Jombang. Pasalnya, pemberlakuan belajar dalam jaringan (daring) memicu sekelumit masalah di masyarakat. Terlebih, Jombang adalah salah satu kawasan yang masih tergolong daerah pelosok. Maka dari itu, penelitian kali ini dimaksudkan untuk mencaritahu bagaimana proses pembelajaran dalam jaringan yang dilakukan oleh masyarakat di Kabupaten Jombang selama pandemi COVID-19 serta mencari apa saja kendala yang terjadi dan bagaimana nilai efektivitasnya pada pemberlakuan belajar daring ini bagi masyarakat Jombang.

\section{METODE PENELITIAN}

Jenis penelitian yang digunakan dalam penelitian ini adalah metode deskriptif kualitatif. Creswell (dalam Semiawan, 2010: 7) mendefinisikan bahwa penelitian kualitatif deskriptif adalah suatu penelitian yang dilakukan dengan menggunakan pendekatan atau penelusuran untuk mengeksplorasi dan memahami suatu gejala sentral. Selain itu, penelitian kualitatif pun bertujuan untuk memahami pandangan individu, mencaritemukan dan menjelaskan proses, dan menggali informasi mendalam tentang subjek penelitian.

Untuk memaksimalkan proses dan hasil penelitian, maka penulis pun mengambil teknik tambahan berupa studi literatur 
sederhana. Dimana penulis mengambil beberapa literatur yang sesuai dengan penelitian untuk dikaji, diolah, dan diambil kesimpulan serta informasi yang sarat makna. Demi keberlangsungan proses penelitian yang memberikan hasil maksimal, penulis menggunakan instrumen penelitian yang terkonsep dengan baik. Pasalnya, semakin baik instrumen penelitian maka hasil atau data dari penelitian pun akan lebih baik juga.

Adapun teknik pengumpulan data yang merupakan suatu kegiatan yang dilakukan peneliti guna mendapatkan data-data secara detail dan tepat. Dalam penelitian kali ini, penulis mengambil teknik pengumpulan data sesuai instrumen yang sudah ditetapkan. Instrumen yang digunakan dalam penelitian ini berupa teks wawancara juga angket yang diberikan pada pihak-pihak yang menjadi subjek penelitian.

Jenis wawancara yang digunakan dalam penelitian ini berupa wawancara semiterstruktur. Jenis angket yang digunakan dalam penelitian ini adalah angket terbuka. Angket terbuka merupakan angket yang berisi pertanyaan atau pernyataan yang dapat diisi bebas oleh responden. Ditambah dengan peninjauan beberapa literatur dan dokumen yang merupakan catatan peristiwa yang sudah berlalu. Menurut Sugiyono (2014: 82) dokumen bisa berbentuk tulisan, gambar, atau karya-karya monumental dari seseorang.

Dalam proses penelitian, tentu tidak selamanya berjalan lancar. Terlebih karena keterbatasan penulis dalam menjangkau seluruh populasi yang ada di kawasan Kabupaten Jombang. Karena keterbatas tersebut, maka penulis memutuskan untuk melakukan penelitian dengan mennggunakan sampel yang spesifik dan tepat sasaran. Dimana sampel inilah yang akan dijadikan sebagai subjek penelitian. Adapun teknik yang digunakan dalam pengambilan sampel ini yakni menggunakan teknik purposive sampling, atau teknik pengambilan sampel yang lebih spesifik. Atau dalam kata lain, sampel yang diambil adalah khusus pihak tertentu atau orang-orang yang punya keterkaitan dengan masalah yang diteliti.

Adapun sampel yang diambil untuk proses penelitian ini terbatas pada beberapa pihak diantaranya: (1) Pihak berwenang yang punya keterkaitan dengan masalah pendidikan di Jombang (Disdikbud Jombang); (2) Guru atau tenaga pendidik di Kabupaten Jombang; (3) Peserta didik di Kabupaten Jombang; (4) Orangtua siswa di Kabupaten Jombang. Sesuai dengan kebijakan pemerintah karena masih masa pandemi, maka proses penelitian dilakukan secara online melalui berbagai media sosial.

\section{HASIL DAN PEMBAHASAN}

\section{Kondisi Belajar Daring di Jombang Selama Pandemi}

Kabupaten Jombang adalah salah satu kawasan yang berada di Jawa Timur. Jombang menjadi salah satu daerah yang memiliki riwayat penyebaran COVID-19 cukup tinggi. Dikutip dari Radar Jombang (2020), Kabupaten Jombang masih dianggap darurat corona bahkan perkembangannya kian memprihatinkan. Dari 21 jumlah kecamatan di Kabupaten Jombang, 18 diantaranya masih berstatus zona merah. Tentunya hal tersebut memicu pemberlakuan pshycal distancing yang akan terus diperpanjang.

Pemberlakukan pembatasan sosial ini akan sangat berdampak pada dunia dan sistem pendidikan di Jombang. Sampai saat ini, Jombang masih menerapkan metode belajar daring. Belajar daring menjadi salah satu isu yang berdampingan dengan kasus pandemi COVID-19. Pasalnya, metode belajar dalam jaringan yang disebut juga sebagai pendidikan jarak jauh (PJJ) membawa berbagai pro-kontra di masyarakat. Khususnya berbagai pihak yang berkaitan dengan sistem pendidikan. Pada dasarnya, pendidikan jarak jauh ini memiliki beberapa arti. PJJ adalah proses pendidikan yang terorganisasi yang menjembatani keterpisahan antara siswa dengan pendidik dan dimediasi oleh pemanfaatan teknologi, dan pertemuan tatap muka yang minimal. Pendidikan jarak jauh juga ditawarkan atas lintas ruang dan waktu sehingga siswa memperoleh fleksibilitas belajar dalam waktu dan tempat yang berbeda, serta menggunakan beragam sumber belajar. Adapun proses pembelajarannya berbentuk pendidikan massif. Pada dasarnya, Pendidikan Jarak Jauh berevolusi dari bentuk pendidikan 
koresponden sampai pendidikan melalui elearning lintas ruang dan waktu. (Paulina, 2016).

\section{Kendala Belajar Daring}

Terhitung sudah 8 bulan berlalu, proses belajar online masih juga tidak berlangsung secara maksimal. Banyaknya siswa yang tidak punya gawai dan akses jaringan internet menjadi kendala paling umum dalam pelaksanaan pembelajaran jarak jauh ini. Bahkan, kebanyakan dari mereka harus sengaja belajar berkelompok dan menumpang kepada temannya yang memiliki gawai serta akses internet (Republika, 2020).

Bagi beberapa wilayah di Indonesia, mungkin metode belajar daring masih dianggap biasa dan bisa berjalan dengan normal tanpa kendala. Namun, di kawasan yang terbilang belum adanya pemerataan sarana dan prasarana, proses belajar online menjadi sebuah momok baru yang sulit dihindari. Pada penelitian ini, penulis menemukan sebuah temuan dimana masyarakat di Kawasan Jombang merasa kurang maksimal dalam belajar daring. Bahkan, beberapa pihak dari mereka merasa tidak setuju dengan adanya pembelajaran ini. Hal ini dikarenakan banyaknya kendala yang dirasakan oleh masyarakat di sana.

Berdasarkan wawancara yang dilakukan pada sampel, yakni orangtua, pelajar, dan guru, maka hasilnya adalah sebagai berikut:

\section{a. Kendala Peserta Didik}

Selama pemberlakuan belajar online atau PJJ, banyak peserta didik yang merasa proses belajarnya tidak efektif. $82 \%$ dari mereka mengatakan bahwa PJJ membuat pelajaran jadi lebih sulit dipahami. Ditambah dengan kesulitan dalam mengakses jaringan, tidak memiliki sarana yang memadai untuk belajar online, hingga rasa bosan. Bahkan, beberapa kasus menyebutkan bahwa proses belajar di masa pandemi secara daring, membuat tingkat semangat belajar jadi turun.

Hal tersebut pun sesuai dengan yang diungkapkan oleh anggota Komisi D DPRD Jombang, Mustofa kepada Radar Jombang (2020), dimana semua pihak sedang mencari slusi untuk melanjutkan proses belajar mengajar yang lebih efektif. Pasalnya, pihak mereka pun menilai bahwa anak-anak di daerahnya merasa kesulitan ketika belajar secara online.

\section{b. Kendala Wali Murid/ Orang Tua}

Kendala belajar daring pun dirasakan oleh orang tua murid. Biasanya pihak orang tua hanya mengawasi proses belajar saat anakanaknya mengerjakan PR atau mengulang pelajaran. Selama pandemi, mereka dipaksa untuk selalu ikut belajar dengan anak-anaknya. Terlebih bagi para orangtua siswa sekolah dasar yang hampir $80 \%$ mengerjakan setiap tugas anak-anaknya.

Ada juga yang merasa geram, sebab pembelajaran dilakukan daring, para orangtua yang kelimpungan, namun harus dibebankan dengan biaya-biaya sekolah. Misalnya saja biaya SPP atau administrasi bulanan. Ditambah dengan kurangnya kemampuan digital orang tua, terlebih yang sudah usia lanjut sehingga sulit sekali membantu anakanaknya ketika belajar di rumah.

\section{c. Kendala Guru}

Tak hanya siswa dan orang tua, pihak guru pun ikut merasa bahwa efektivitas belajar daring belum maksimal. Menurut pandangan beberapa guru di Jombang, bukan hal mudah untuk beradaptasi dengan konsep pembelajaran yang berbeda dari biasanya. Menyiapkan materi pelajaran, menyiapkan soal-soal, hingga sarana pendukung proses belajar. Dari mulai membuat materi yang relevan, proses share ke media online, memenuhi ruang aplikasi pesannya dengan grup siswa, dirumitkan dengan segala pertanyaan orangtua dan siswa. Meskipun pihak kementrian sudah memberikan modul untuk membantu proses pembelajaran daring, namun tidak semua guru bisa mengaksesnya dengan mudah.

\section{Efektivitas Belajar Daring di Jombang}

Mustofa dalam Radar Jombang (2020) menyebutkan bahwa berbagai lapisan masyarakat khususnya pihak pemerintah pusat, pemerintah daerah terus berupaya untuk mencari beragam solusi agar pembelajaran bisa dilakukan dengan maksimal karena berkenaan dengan pendidikan generasi bangsa. Apalagi dengan adanya metode belajar online yang dinilai kurang efektif apalagi kawasan 
Kabupaten Jombang masih terkendala dengan sarana prasana. Terlebih, bantuan dan kerjasama pihak orangtua pun cukup besar. Belum lagi ketika pihak siswa tidak memiliki gawai dan akses internet. Meskipun memang sudah ada surat edaran tentang dibolehkannya proses belajar normal, namun karena kebanyakan kawasan di Kabupaten Jombang masih berstatus zona merah, sehingga proses belajar belum diperbolehkan secara tatapmuka atau secara langsung.

\section{KESIMPULAN}

Berdasarkan analisis yang sudah dilakukan oleh penulis, terlebih dengan banyaknya kendala yang dirasakan oleh masyarakat khususnya pihak-pihak yang berkenaan dengan metode belajar daring di Kabupaten Jombang, bisa diketahui bahwa proses belajar dalam jaringan (daring) masih belum mencapai tingkat efektivitas yang diharapkan. Bahkan, dengan banyaknya kendala ketika melakukan proses belajar online membuat siswa, orangtua, bahkan guru merasa kelimpungan dalam menghadapinya. Keterbatasan sarana dan prasarana penunjang, seperti masih banyak masyarakat yang belum memiliki gawai serta akses internet, serta kurangnya kemampuan masyarakat dalam menggunakan teknologi digital, menambah ketidakefektifan belajar daring.

\section{SARAN}

Menilik pada proses belajar daring di Kabupaten Jombang, Jawa Timur yang masih belum efektif, maka diperlukan solusi untuk mengatasinya. Pasalnya, kesuksesan proses belajar di masa pandemi secara online, tentu tidak bisa dilakukan oleh salah satu pihak saja. Perlu semua pihak yang ikut andil dan berperan untuk menyukseskannya. Dari mulai masyarakat yang sebaiknya mulai mencoba untuk peka dan melek terhadap tantangan zaman di era digital, juga pihak pemerintah dan lembaga terkait untuk melakukan pemerataan sarana prasarana bagi orang-orang yang tidak mampu menggapainya. Pun koordinasi dan komunikasi dari semua pihak sangat berarti untuk memaksimalkan proses belajar di masa sulit seperti saat ini.

\section{DAFTAR PUSTAKA}

Buana, D. R. (2020). Analisis Perilaku Masyarakat Indonesia dalam Menghadapi Pandemi Virus Corona (Covid-19) dan Kiat Menjaga Kesejahteraan Jiwa. National Research Tomsk State University, Universitas Mercu Buana

Deutsch, Jillian. (2020). "How Long Will It Take to Develop a Coronavirus Vaccine?". POLITICO. Retrieved November 23, 2020. Interact website: https://www.politico.eu/article/corona virus-vaccine-how-long-will-it-taketodevelop/

Menpan. (2020). Aturan Baru Sistem Kerja ASN Berdasarkan Kategori Zonasi Risiko Wilayah. Retrieved November 23, 2020. Interact website: https://www.menpan.go.id/site/beritaterkini/aturan-baru-sistem-kerja-asnberdasarkan-kategori-zonasi-risikowilayah

Mustakim. (2020). Efektivitas Pembelajaran Daring Menggunakan Media Online Selama Pandemi COVID-19 Pada Pelajaran Matematika. Al asma: Journal of Islamic Education. 2 (1). 112

Paulina. (2016). Kebijakan PJJ dan ELearning. Retrieved November 23, 2020. Interact website: http://kopertis3.or.id/v2/wpcontent/uploads/Paulina-PannenKebijakan-PJJ-dan-E-Learning.pdf

Radar Jombang. (2020). Jombang Masih Darurat Korona. Retrieved November 23, 2020. Interact website: https://radarjombang.jawapos.com/rea d/2020/11/23/226315/jombang-masihdarurat-korona

Republika. (2020). Kendala Belajar Daring di Wilayah Pelosok Jombang. Retrieved November 23, 2020. Interact website: https://republika.co.id/berita/qdv1e428 3/kendala-belajar-daring-di-wiayahpelosok-jombang

Ririn. (2020). Indonesia dalam Menghadapi COVID-19. Jurnal Ilmiah Universitas Batanghari Jambi. 20 (2). 705-709 
Rohendi, Tjetjep. (1992). Analisis Data Kualitatif. Jakarta: Universitas Indonesia

Semiawan. (2010). Metode Penelitian Kualitatif. Jakarta: Grasindo

Sohrabi C, Alsafi Z, O’Neill N, et al. (2020). World Health Organization declares global emergency: A review of the 2019 novel coronavirus (COVID19). International Journal of Surgery. 76, 71-76.

Sugiyono. (2014). Metode Penelitian Pendidikan Pendekatan Kuantitatif, Kualitatif, dan R\&D. Bandung: Alfabeta

WHO. (2020, March 11). Retrieved from WHO Director-General's opening remarks at the media briefing on COVID-19. November 23, 2020. Interact website: https://www.who.int/dg/speeches/detai 1/who-director-general-sopeningremarks-at-the-mediabriefing-on-covid19---11-march-2020

Worldometers. (2020). Retrieved from COVID-19 Coronavirus Pandemic in Indonesia. November, 23. 2020. Interact website: https://worldometers.info/coronavirus/ country/indonesia/

Yuliana. (2020). Corona Virus Disease (Covid-19); Sebuah Tinjauan Literatur. Wellness and Healthy Magazine, 2(1), 187-192. 